\title{
Új lehetöség a szisztolés szívelégtelenség (HFrEF) kezelésében: omecamtiv-mecarbil
}

\author{
Ráduly Arnold Péter', Tóth Attila', Papp Zoltán', Borbély Attila, 2
}

\author{
1Debreceni Egyetem, Általános Orvostudományi Kar, ${ }^{1}$ Kardiológiai Intézet, Klinikai Fiziológiai Tanszék, \\ ${ }^{2}$ Kardiológiai Intézet, Kardiológiai Tanszék, Debrecen
}

Levelezési cím:

Dr. Borbély Attila, Debreceni Egyetem, Általános Orvostudományi Kar, Kardiológiai Intézet, Kardiológiai Tanszék 4032 Debrecen Móricz Zsigmond krt. 22. E-mail: borbelya@med.unideb.hu

\begin{abstract}
A szívelégtelenség továbbra is igen magas mortalitású és morbiditású kórkép. A csökkent ejekciós frakciójú szívelégtelenség (HFrEF) kezelésében kiemelt jelentőséggel bírnak a szív pumpafunkcióját javító szerek. Továbbra is igen kevés olyan gyógyszer áll rendelkezésünkre, amelyek hatékonyan képesek javítani a kontraktilitást, ugyanakkor biztonságosak, nem növelik a szívizom oxigén- és energiaigényét. Az elmúlt évtizedben jelentős figyelem kísérte az aktin-miozin kereszthíd-ciklus direkt módosíthatóságát. Az első ilyen hatásmechanizmusú gyógyszerjelölt, amely eljutott a III. fázis klinikai vizsgálatokig az omecamtiv-mecarbil. Jelen áttekintő közlemény célja, hogy összefoglaljuk az omecamtiv-mecarbillal kapcsolatos, a klinikai gyakorlat szempontjából is releváns ismereteket, valamint a szerrel végzett, nemrégiben publikált GALACTIC-HF klinikai vizsgálat legfontosabb eredményeit.
\end{abstract}

Kulcsszavak: szívelégtelenség, HFrEF, pozitív inotrópia, direkt miozin-aktivátorok, omecamtiv-mecarbil

Novel therapeutic approach to systolic heart failure (HFrEF) management: omecamtiv mecarbil Heart failure remains a disease with very high mortality and morbidity. Agents that improve cardiac contractile function are of paramount importance in the treatment of heart failure with reduced ejection fraction (HFrEF). Only few drugs are available to improve contractility in a safe manner (i.e. in the absence of increased myocardial oxygen and energy demands). Particular attention surrounded the direct modulation of the actin-myosin crossbridge cycle in the past decade. The first drug candidate with such a mechanism of action to reach a phase III clinical trial is omecamtiv mecarbil. The purpose of this review is to summarize the knowledge of omecamtiv mecarbil that is also relevant to clinical practice, as well as to present the main results of the recently published GALACTIC-HF clinical trial.

Keywords: heart failure, HFrEF, positive inotropy, cardiac myosin activators, omecamtiv mecarbil

\section{Bevezetés}

Szívelégtelenség: epidemiológia, társadalmi és gazdasági jelentőség, klinikai osztályozás

A szívelégtelenség a fejlett társadalmak egyik leggyakoribb betegsége, prevalenciája kb. $2 \%$, a kórkép incidenciája folyamatosan növekszik. Hazánkban mintegy
2-300 ezer szívelégtelen beteg él (1). Annak ellenére, hogy az utóbbi években a kórkép gyógyszeres, illetve eszközös kezelésében is jelentős fejlődés következett be, a betegség mortalitása még mindig igen magas, az első hospitalizációt követő 5 éven belül a betegek $70 \%$-át elveszítjük $(2,3)$. Ez a mortalitási arány összemérhető több malignus megbetegedés halálozásával, 
csak olyan súlyos daganatos megbetegedések előzik meg, mint a gyomor, a nyelőcső, a tüdő és a hasnyálmirigy rosszindulatú elváltozásai (4). A szívelégtelenség a 65 év feletti populációban a hospitalizáció leggyakoribb oka, ezáltal jelentős gazdasági terhet ró mind a társadalomra, mind pedig az egészségügyi ellátórendszerre (5).

Az Európai Kardiológiai Társaság jelenleg érvényben lévő, 2016-ban publikált irányelve alapján a bal kamrai ejekciós frakció (BKEF) alapján a szívelégtelenség három fő klinikai formáját különböztetjük meg:

1. szívelégtelenség csökkent ejekciós frakcióval (HFrEF), BKEF <40\%;

2. szívelégtelenség közepes mértékben csökkent ejekciós frakcióval (HFmrEF), (BKEF 40-49\%);

3. szívelégtelenség megtartott ejekciós frakcióval (HFpEF), (BKEF $\geq 50 \%$ ) (6).

A HFrEF egy progresszív lefolyású klinikai szindróma, amelynek legfőbb klinikai jellemzője a szív pumpafunkciójának romlása. A betegség patomechanizmusában a renin-angiotenzin-aldoszteron rendszer (RAAS), illetve a szimpatikus idegrendszer túlzott aktiválódása kiemelt jelentőséggel bír. Ezen két rendszer gátlásán alapszik a HFrEF bázisterápiája, amely gyógyszerek (RAAS-gátlók, béta-blokkolók, mineralokortikoid-receptor-antagonisták) már számos klinikai vizsgálatban bizonyították mortalitáscsökkentő hatásukat (4). A HFrEF lefolyása során a hirtelen fellépő állapotromlások (kardiális dekompenzáció) a szív pumpafunkciójának további károsodásához vezetnek. Ezen periódusokban szüksé- gessé válhat olyan gyógyszerek alkalmazása, amelyek képesek a szívizom kontraktilitásának javítására. Erre a célra alkalmazott készítmények a pozitív inotróp szerek, amelyek közül mindeddig nem sikerült azonosítani olyat, amely képes lett volna javítani a HFrEF-betegek mortalitását. Egyes szerek esetén - mortalitást fokozó hatásuk miatt - a klinikai vizsgálat idő előtti leállítása vált szükségessé $(5,6)$.

\section{Pozitív inotróp szerek: csoportosítás és hatásmechanizmus}

A pozitív inotróp szerek három különböző hatásmechanizmussal képesek javítani a szív pumpafunkcióját (1. ábra).

Az úgynevezett „upstream” mechanizmus útján ható szerek különböző jelátviteli útvonalak, illetve transzporterek működésének befolyásolása révén növelik az intracelluláris kalciumion $\left(\mathrm{Ca}^{2+}\right)$-koncentrációt (9). Ebbe a csoportba sorolhatók a konvencionális pozitív inotróp szerek: a digitális származékok, amely a szarkolemmában található $\mathrm{Na}^{+} / \mathrm{Ca}^{2+}$ cserélő müködését gátolják, a dobutamin, amely a $\beta_{1}$-receptorok aktivációján keresztül fejti ki hatását és a foszfodiészteráz-enzim-3 (PDE3)-gátló milrinon, amely az intracelluláris tér ciklikus adenozin-monofoszfát (cAMP) tartalmát növeli. Ezek a szerek energetikai szempontból előnytelenek, növelik a szívizom oxigénfogyasztását, ugyanis az általuk befolyásolt útvonalak ATP-igényesek. Ezen túlmenően növelhetik a szívfrekvenciát is. Ismert, hogy a konvencionális pozitív inotróp szerek nem javítják,

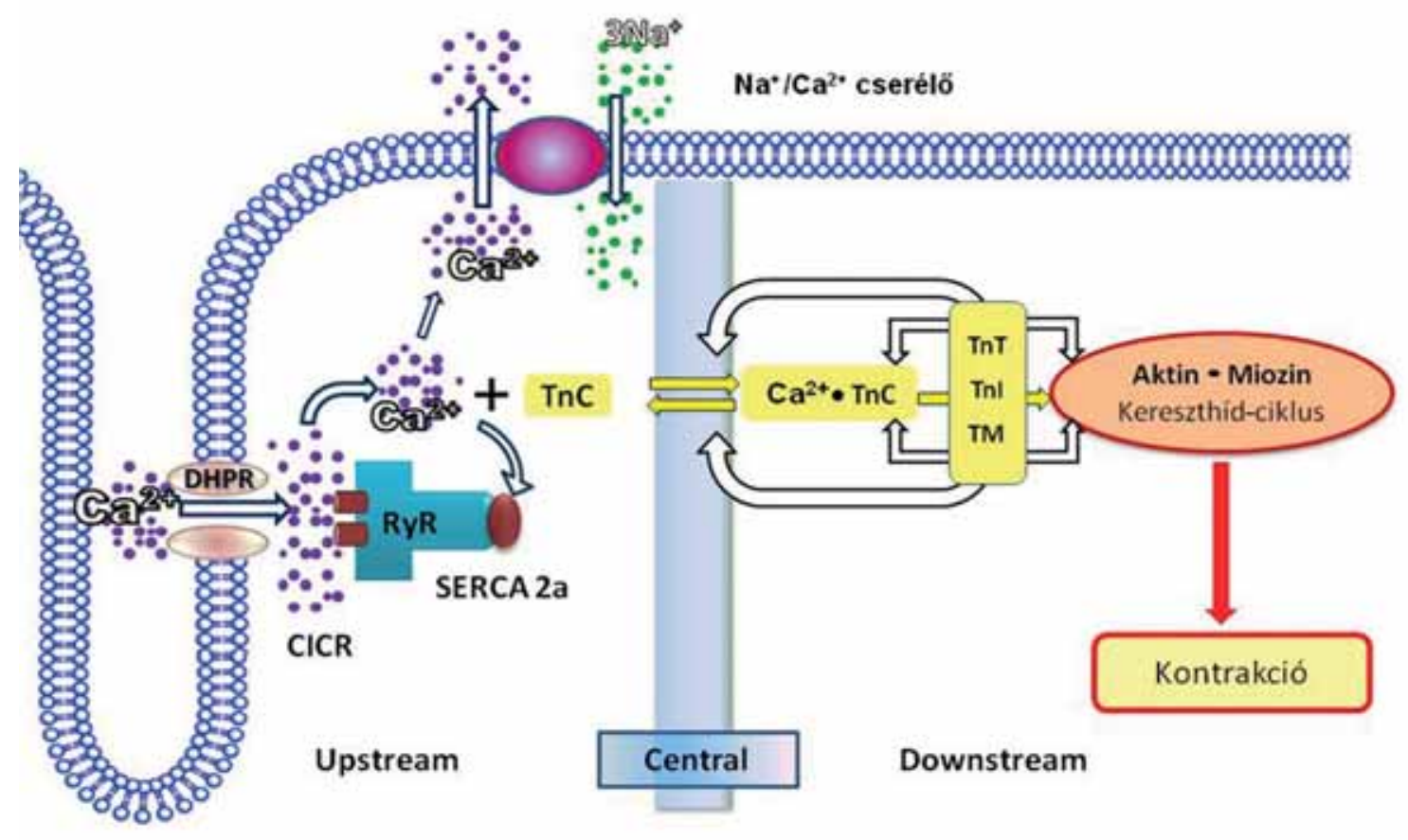

1. ÁBRA. A pozitív inotróp szerek csoportosítása és hatásmechanizmusai (magyarázat a szövegben) (Rövidítések: Ca ${ }^{2+}$ kalcium; CICR: Ca ${ }^{2+}$ indukálta Ca ${ }^{2+}$-felszabadulás; DHPR: dihidropiridin-receptor; RyR: rianodin-receptor; SERCA2a: szarkoplazmatikus retikulum ATPáz; TnC, Tnl és TnT: troponin C, I és T; TM: tropomiozin) (módosítva Endoh M.: Circ J 2008; 72: 1915-25. alapján) 
egyes esetekben pedig növelik a HFrEF-betegek mortalitását (7). Alkalmazásuk a lehető legrövidebb ideig, kizárólag hipotenzió (szisztolés vérnyomás < 90 Hgmm) és/vagy megfelelő töltőnyomás ellenére perzisztáló hipoperfúzió jeleit/tüneteit mutató betegek esetén javasolt a perctérfogat, a vérnyomás növelése, a perifériás perfúzió javítása és a célszervfunkció megőrzése céljából (Ilb osztályú ajánlás, C-evidenciaszint) (6).

A „centrális” mechanizmus útján ható szerek a szívizom összehúzódásának szabályozásában kulcsfontosságú troponin $\mathrm{C}(\mathrm{TnC})$ fehérje $\mathrm{Ca}^{2+}$ iránti affinitását fokozzák, vagyis nem befolyásolják az intracelluláris $\mathrm{Ca}^{2+}$-koncentrációt. Ilyen molekula a levosimendan, amely az ATP-szenzitív káliumcsatornák aktiválószereként vazodilációt is okoz (inodilátor szer). A levosimendan magasabb plazmakoncentrációk esetén PDE3-gátló hatással is rendelkezik (10).

A „downstream” mechanizmus útján ható szerek az aktin és a miozin között létrejövő kapcsolatot, a kereszthíd-ciklust direkten befolyásolják, vagyis nem növelik az intracelluláris $\mathrm{Ca}^{2+}$-szintet. Utóbbi miatt az ebbe a csoportba tartozó molekulák mentesek az „upstream” mechanizmus során felsorolt káros hatásoktól. Az első ilyen hatásmechanizmusú gyógyszer, amely III. fázis klinikai vizsgálatban is kipróbálásra került az omecamtiv-mecarbil (OM) (11).

\section{Omecamtiv-mecarbil}

Történeti áttekintés, a molekula kifejlesztése Az OM felfedezésének története a kétezres évek elejére nyúlik vissza. Egy gyógyszerkutató cég nagy áteresztőképességű módszert (HTS) alkalmazva, olyan vegyületeket keresett, amelyek képesek a sejtosztódás kinetikájában kiemelkedő jelentőségü kinezinfehérjék funkcióját gátolni. Egy olyan molekulára bukkantak azonban, amely fokozza ezen fehérjék müködését. További, a miozin ATPáz aktivitását vizsgáló kísérletek során egy olyan molekulát azonosítottak, amely már alacsony, mikromolos koncentrációban képes a miozin aktiválására. Ezen vegyület különböző kémiai módosításaival jutottak el az in vivo kísérletekre is alkalmas gyógyszerjelölt molekulához, az omecamtiv-mecarbilhoz (CK-1827452) (12).

\section{Az OM hatásmechanizmusa}

Az OM egy heterociklusos, mind intravénás és mind per os terápiára alkalmas kémiai vegyület. A szer pontos hatásmechanizmusának megértéséhez röviden érdemes áttekinteni a szívizomzat erőgenerálás szempontjából legfontosabb elemi egységek, a szarkomerek felépítését és funkcióját. A szarkomerek megtalálhatók mind szív-, és vázizomrostokban, azok harántcsíkolt megjelenéséért felelősek, amelyek akár fénymikroszkóppal vizsgálva is láthatók. A miokardiális erőgenerálás élettani alapja a szarkomert dominánsan felépítő „vastag” (elsősorban miozin) és „vékony” (elsősorban aktin) filamentumok ismételt szabályozott kapcsolódása és a vékony filamentumok vastaghoz képesti elcsúszása. A miozinfehérjék a motoros fehérjék nagy családját képezik és olyan élettani funkciók szabályozásában játszanak fontos szerepet, amelyben a mozgás kiemelt jelentőségü. Így könnyen érthető, hogy az izomkontrakcióban betöltött szerepük esszenciális. A miozinfehérjék alapvető jellemzője az aktinkötő-képesség, az ATPáz-aktivitás, azaz ATP hidrolizálóképesség és az ebből nyert kémiai energia konvertálása fizikai energiává, az izomösszehúzódás kivitelezéséhez (13). Az OM szelektíven kötődik a kardiális típusú miozinfehérjének feji részén található S1-régióhoz, így allosztérikusan pozitívan befolyásolja a miozin ATPáz aktivitását, ezáltal gyorsítva az anorganikus foszfát (Pi) disszociációját a miozinfejekről, amely az aktomiozin ciklus sebességmeghatározó lépése. Ennek köszönhetően az aktinhoz csak gyengén kötődő miozin-ATP komplexből hamarabb, illetve nagyobb sebességgel keletkezik az aktinhoz erősebben kötődő miozin-ADP komplex az Pi diszszociációját követően, amelyet az erőgenerálási lépés kísér. Ezen folyamatok eredményeként egyszerre több aktin-miozin kapcsolat alakul ki, amely a kontraktilis erő növekedését eredményezi $(12,13)$.

\section{Klinikai vizsgálatok omecamtiv-mecarbillal}

\section{Dóziskereső vizsgálatok}

$A z$ első, egészséges embereken végzett kettős vak, placebokontrollált, dóziskereső (II. fázis) vizsgálat eredményeit 2011-ben publikálták. Ennek során 34, 18-50 év közötti egészséges férfi kapott intravénásan OMet (időtartam 6 óra, dózis 0,005-1,0 mg/kg/óra) vagy placebót. Az OM-csoportban dózisfüggő növekedést tapasztaltak a szisztolés ejekciós időben (SET), az ejekciós frakcióban (EF) és bal kamrai frakcionális rövidülésben (FS). Az OM 0,625 mg/kg/óra dózisig jól tolerálható volt, ezen dózis felett azonban a SET jelentős megnyúlását észlelték, amely a diasztolés idő rövidüléséhez, és a koronáriaperfúzió feltételezett romlásához vezetett (16).

Ezt követően az OM-et 45 stabil, sinusritmusban lévő, optimális gyógyszeres kezelésben részesülő HFrEF-betegben vizsgálták (BKEF <40\%). További kritérium a jó echokardiográfiás ablak megléte volt. A vizsgálat során a korábbi dóziskereső vizsgálat eredményei alapján az OM plazmakoncentrációja nem haladta meg az 1200 $\mathrm{ng} / \mathrm{ml}$-t (ezen érték felett mellékhatások megjelenését tapasztalták). A vizsgálatba bevont HFrEF-betegek többsége az alkalmazott koncentrációkban jól tolerálta a gyógyszert, egyes echokardiográfiás paraméterekben (SET, FS, pulzustérfogat) pedig javulást tapasztaltak (17).

Az OM hatásait iszkémiás szívbetegségben szenvedő HFrEF-betegeken is vizsgálták terhelés során (BKEF 
$<35 \%$, BK végdiasztolés átmérő $>55 \mathrm{~mm}$, BK végdiasztolés átmérő index $>32 \mathrm{~mm} / \mathrm{m}^{2}$ ). A vizsgálat $a z$ OM biztonságosságát, illetve alkalmazhatóságát vizsgálta abban a betegpopulációban, akik a legérzékenyebben reagálhatnak a korábbi vizsgálatokban mért SET-növekedésre. Azon betegek kerültek beválogatásra, akik miokardiális infarktuson estek át (CK-MB-, Tnlvagy $\mathrm{TnT}$-emelkedés, patológiás $\mathrm{Q}$-hullám jelenléte az EKG-n), vagy akik esetében koronarográfia során legalább az egyik nagy epikardiális éren $>60 \%$-os szükület igazolódott. A beválogatott 94 beteget 2:1 arányban randomizálták OM-re, illetve placeboágra. A betegeket futópadon terhelték, 20 órás OM-infúzió előtt, illetve azt követően. A vizsgálat során nem találtak szignifikáns különbségeket sem a mellékhatásokban, sem pedig terhelési kapacitásban kontroll és az OM-mel kezelt csoport között. A vizsgálat fő limitációja az alacsony betegszám volt, így az OM terhelési kapacitásra kifejtett hatásáról nehéz véleményt formálni (18).

\section{ATOMIC-HF-tanulmány (Acute Treatment With Omecamtiv Mecarbil to Increase Contractility in Acute Heart Faillure)}

A fentiekben bemutatott, az intravénás OM-kezelés hatásait vizsgáló tanulmányok kedvező eredményei megfelelő alapot szolgáltattak nagyobb betegszámú, III. fázis vizsgálatok elvégzésére is. Az ATOMIC-HF placebokontrollált, kettős vak elrendezésủ vizsgálatban 606 akut szívelégtelenségben szenvedő (BKEF <40\%, emelkedett NT-proBNP-szint, nehézlégzés) betegben alkalmazták intravénásan az OM-et három különböző koncentrációban. A primer végpontban, amely a nehézlégzés csökkenése volt, az OM-mel kezelt betegcsoportban nem találtak szignifikáns különbséget a placebóhoz képest. A legmagasabb OM-dózis esetén azonban, az adott kontrollcsoporthoz képest 41\%-kal nagyobb arányban csökkent a nehézlégzés. Emellett a SET dózisfüggő megnyúlása, a szisztolés vérnyomás növekedése, illetve a bal kamrai végdiasztolés átmérő csökkenése volt megfigyelhetö. Az OM-mel kezelt betegekben kismértékben emelkedett troponin I-szinteket mértek, ugyanakkor ez nem mutatott összefüggést az alkalmazott OM-dózissal. A placebo- és az OM-csoportok összehasonlításakor nem volt különbség az adverz események (szívelégtelenség, hipotenzió, hypokalaemia, akut veseelégtelenség, pitvari és kamrai ritmuszavarok) előfordulási gyakoriságában (19).

\section{COSMIC-HF-tanulmány (Chronic Oral Study of Myosin Activation to Increase Contracti- lity in Heart Failure)}

Ezen vizsgálat az orálisan alkalmazott OM farmakokinetikájának és a bal kamrai paraméterekre kifejtett hatásának vizsgálatát tűzte ki célul stabil krónikus HFrEF-ben (448 NYHA II-III. funkcionális stádiumú optimális gyógyszeres kezelésben részesülő beteg esetén). Mindazon betegek kizárásra kerültek, akik
30 napon belül akut miokardiális infarktuson estek át, instabil anginában, illetve súlyos krónikus veseelégtelenségben szenvedtek. A placebocsoport mellett egy fix dózisú (napi 2×25 mg OM), illetve egy farmakokinetikai szempontok alapján titrált (napi $2 \times 25-50 \mathrm{mg} \mathrm{OM}$ ) betegcsoportot is kialakítottak, a betegek a kezelést 20 hétig kapták. A farmakokinetikai jellemzők alapján titrált betegcsoportban a placebocsoporthoz képest szignifikánsan magasabb SET-et és verőtérfogatot, valamint a $B K$ végszisztolés és végdiasztolés átmérő, a szívfrekvencia és az NT-proBNP-plazmaszint csökkenését figyelték meg a 20 hétig tartó kezelést követően (20).

\section{GALACTIC-HF-vizsgálat (Global approach to Lowering Adverse Cardiac outcomes Through Improving Contractility in Heart Failure) \\ A vizsgálat felépítése, végpontok}

A GALACTIC-HF egy multicentrikus, randomizált, kettős vak, placebokontrollált vizsgálat, amelynek célja az OM hatékonyságának és biztonságosságának vizsgálata volt HFrEF-betegeken. A vizsgálat felépítését a 2 . ábra szemlélteti. A vizsgálat elsődleges végpontja a gyógyszer alkalmazásának kezdete és az első szívelégtelenség miatti esemény vagy kardiovaszkuláris (CV) okból bekövetkező halálozás között eltelt idő volt. A vizsgálatba összesen $8256 \mathrm{HFrEF-beteg} \mathrm{került} \mathrm{be-}$ választásra kórházi bennfekvés során vagy ambuláns gondozás keretein belül.

\section{Beválasztási és kizárási kritériumok}

A vizsgálatba 18-85 év közötti, jelenleg vagy egy éven belül szívelégtelenség miatt hospitalizált/sürgősségi osztályon szívelégtelenség miatt megjelent, randomizáció előtt legalább 30 napig szívelégtelenség bázisterápián lévő, tünetes, HFrEF-betegek kerültek beválogatásra (BKEF <35\%, NYHA II-IV. funkcionális stádium, optimális szívelégtelenség bázisterápia, vagy szívelégtelenség miatti hospitalizáció utáni gyógyszertitrálási fázis, BNP $>125 \mathrm{pg} / \mathrm{ml}$ vagy NT-proBNP $>400 \mathrm{pg} / \mathrm{ml} \mathrm{si-}$ nusritmus, illetve $>375 \mathrm{pg} / \mathrm{ml}$ és $>1200 \mathrm{pg} / \mathrm{ml}$ pitvarfibrilláció esetén).

A kizárási kritériumok közül a legfontosabbak:

- hemodinamikai instabilitás, a randomizációt megelőző három napban intravénás inotróp vagy vazopresszor alkalmazása;

- súlyos veseelégtelenség (eGFR<20 ml/min/1,73 m²), illetve dialízisben részesülö beteg;

- szisztolés vérnyomás >140 Hgmm vagy < $85 \mathrm{Hgmm}$;

- szívfrekvencia $>110 /$ perc vagy $<50 /$ perc.

A vizsgálat felépítése, végponto $k$

Az OM alkalmazása a COSMIC-HF-tanulmányban használt adagolási séma alapján történt. Az OM kezdődózisa $2 \times 25 \mathrm{mg}$ volt, a plazmakoncentráció céltartományát 200-1000 ng/ml között határozták meg. A 2. 

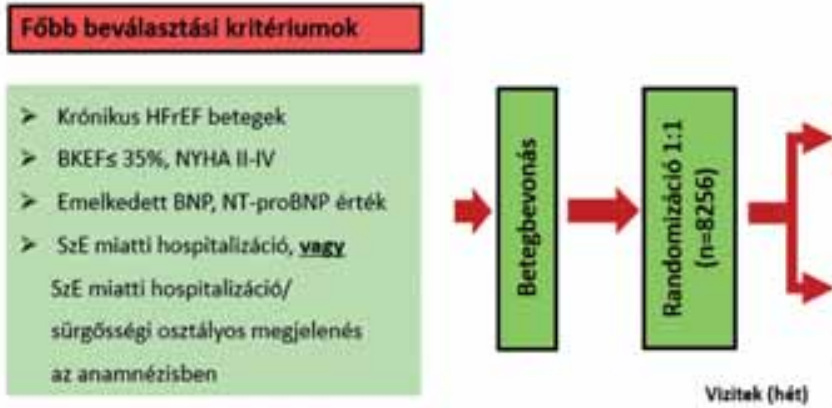

Farmakokinetikai meres dbebtinelibshes Plazmakonsentrició meghataroziss
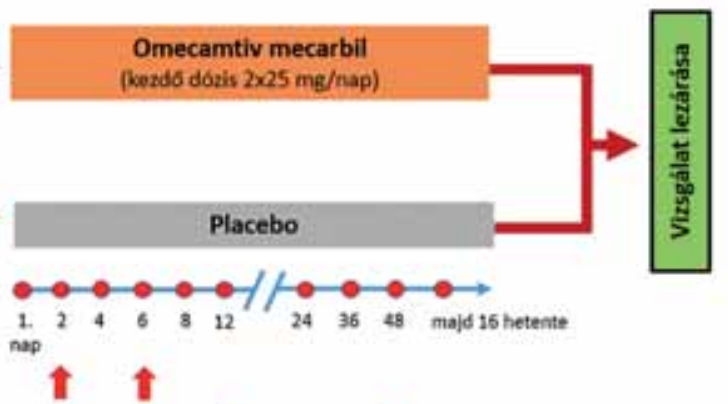

2. ÁBRA. A GALACTIC-HF-vizsgálat felépítése (magyarázat a szövegben)

héten mért plazmakoncentráció alapján a gyógyszer dózisát $2 \times 37,5$ mg-ra vagy $2 \times 50$ mg-ra emelték, céltartomány esetén a kiindulási $2 \times 25$ mg dózissal folytatták, 1000 ng/ml feletti plazmakoncentráció esetén placebóra tértek át. A következő plazmakoncentráció-ellenőrzés a 6. héten történt, majd 8., 12. és 48., majd minden 48. héten. Ami az egyes OM-dózisokat illeti, a farmakokinetikai titrálás alapján a 12. héten az OM-ágon lévő betegek 47,6\%-a volt 2×50 mg-os, 13,6\%-a 2×37,5 mg-os, 28,9\%-a pedig 2×25 mg-os gyógyszerdózison (a betegek 9,9\%-a ezen az ágon nem tudta folytatni a vizsgálatot). Az átlagos utánkövetési idő 21,8 hónap volt. Miokardiális infarktus, vagy miokardiális iszkémia gyanúja esetén azonnal felfüggesztették mind a placebo, mind az OM adását.

A kontrollvizitek (12-16 hetente) alkalmával a nem várt eseményeket és a végpontokat vizsgálták. Az OM tünetekre kifejtett hatását a Kansas City Cardiomyopathia, illetve az EuroQOL-5 kérdőívvel mérték fel az első napon, majd 12 hetente a 48 . hétig, majd évente. A vizsgálat biztonságosságát két interim analízis biztosította. A vizsgálat elsődleges végpontja a CV-halálozás vagy a szívelégtelenség miatti esemény volt. Utóbbi magában foglalta a szívelégtelenség rosszabbodása miatti nem tervezett kórházi felvételt, vagy sürgősségi osztályon történő megjelenést. Másodlagos végpontként a CV vagy egyéb okból bekövetkező halálozás, az első szívelégtelenség miatti hospitalizációig eltelt idő, valamint a Kansas City Cardiomypathia kérdőívben tapasztalt változás (a vizsgálat kezdetétől a 24. hétig) szerepelt (21).

\section{Betegjellemzők, gyógyszeres és eszközös kezelés}

A betegek átlagéletkora mind a placebo- $(n=4112)$, mind az OM- (n=4120) csoportban 64,5 év volt, a nők aránya viszonylag alacsony volt $(21,2$, illetve $21,3 \%)$. A betegek körülbelül negyede szívelégtelenség miatti hospitalizáció során került bevonásra. A betegek több mint a fele iszkémiás cardiomyopathiában, negyedük pitvarfibrillációban szenvedett. A vizsgálatba nagyrészt
NYHA II-III. funkcionális stádiumú betegek kerültek bevonásra. A szívelégtelenség gyógyszeres terápia mindkét vizsgálati csoportban optimális volt (bázisterápia alkalmazási arányok: RAAS-gátlók $87 \%$, béta-blokkolók 94\%, mineralokortikoid-receptor-antagonisták $78 \%$ ). Angiotenzinreceptor-blokkoló neprilizin-inhibitort (ARNI) a betegek 20\%-a kapott, amely az eddig publikált szívelégtelenség tanulmányok közül kiemelkedően magasnak számít. A betegek 14\%-a részesült CRT-kezelésben, ICD-implantáció a betegek közel harmadában történt.

A kiindulási, átlag BKEF $(26,6 \pm 6,3 \%$, illetve $26,5 \pm 6,3 \%)$ és NT-proBNP-értékek (közel 2000 pg/ml) egy előrehaladott stádiumú HFrEF-betegpopulációt jeleztek. Az átlagos eGFR-érték $59 \mathrm{ml} / \mathrm{min} / 1,73 \mathrm{~m}^{2}$ volt.

\section{Eredmények}

$A z$ elsődleges összetett végpont (CV-halálozás vagy szívelégtelenség miatti esemény) előfordulásának relatív rizikója az OM-mel kezelt betegekben szignifikánsan, 8\%-kal alacsonyabb volt a placebót kapó betegekhez képest (HR: 0,92; 95\% Cl: 0,86-0,99, p=0,03) (3. ábra). A szívelégtelenség miatti hospitalizáció $0,7 \%$ kal, szívelégtelenség miatti ambuláns ellátás 0,8\%-kal, CV-okból bekövetkező halálozás 0,6\%-kal gyakoribb volt a placebocsoportban. Így az elsődleges összetett végpont előfordulásának abszolút rizikója 2,1\%-kal volt alacsonyabb az OM-mel kezelt betegekben (37\% vs. 39,1\%, HR: 0,92; Cl: 0,86-0,99, p=0,03). Ha az elsődleges végpont összetevőit külön vizsgálták, akkor a CV-okból bekövetkező halálozás tekintetében nem volt különbség a két betegcsoport között (HR: 1,01; 95\% Cl: 0,92-1,11) (3. ábra), azonban a szívelégtelenség miatti események $1,4 \%$-kal gyakrabban fordultak elő a placebocsoportban.

A másodlagos végpontok tekintetében sem a CV-okból bekövetkező halálozás, sem a Kansas City cardiomyopathia kérdőívben, sem pedig az összhalálozásban nem volt különbség a két betegcsoport között. Az elöre meghatározott alcsoportokban sem találtak szignifi- 


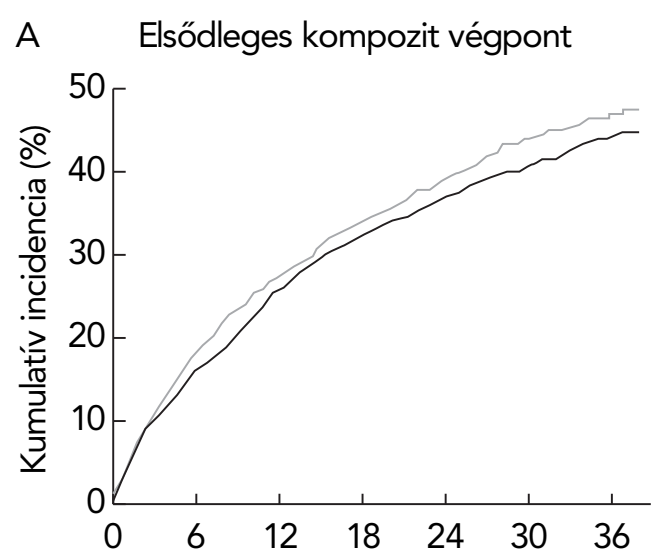

Randomizációtól eltelt idő (hónapok)

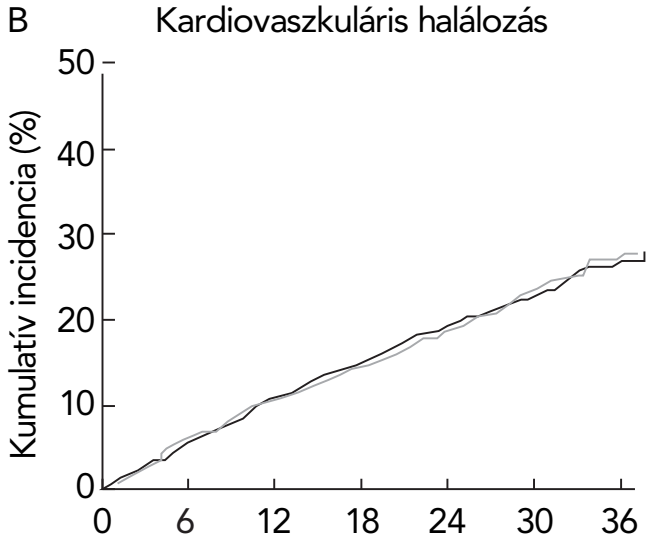

Randomizációtól eltelt idő (hónapok)

Placebo

Omecamtiv mecarbil

3. ÁBRA. A GALACTIC-HF-vizsgálat jelentősebb eredményei. A: Az OM jelentősen csökkentette az elsődleges összetett végpont (kardiovaszkuláris halálozás vagy szívelégtelenség miatti esemény) előfordulásának rizikóját ( $\mathrm{HR} 0,92 ; 95 \% \mathrm{Cl}, 0,86-0,99, \mathrm{p}=0,03)$. B: Az OM nem befolyásolta a kardiovaszkuláris okból bekövetkező halálozást (HR: 1,01; 95\% Cl: 0,92-1,11). (Teerlink JR, et al. Cardiac Myosin Activation with Omecamtiv Mecarbil in Systolic Heart Failure. N Engl J Med 2021 Jan; 384(2): 105-16. alapján)

káns különbségeket az OM-mel kezelt és a placebót kapó betegek között.

\section{Vitális és laboratóriumi paraméterek, biztonságossági végpontok}

A vitális paraméterek közül a szívfrekvencia kismértékü, nem szignifikáns csökkenését figyelték meg az OM-mel kezelt betegekben (1,6, illetve 1,8 ütés/perc a 24. és a 48. héten). Ezen túlmenően kismértékű, nem szignifikáns növekedést észleltek a kardiális troponin I-szintben az OM-mel kezelt csoportban (4, illetve 2 ng/l a 24. és a 48. héten). Az NT-proBNP plazmaszintje a kiindulási értékekhez viszonyítva 10\%-kal nagyobb mértékben csökkent az OM-et kapó betegekben, mint a placebocsoportban. Egyéb vitális, illetve a kezelés biztonságosságát jelző paraméterekben (szérumkáliumés kreatininszint, eGFR), és nem várt eseményekben (pitvari és malignus kamrai ritmuszavarok, iszkémiás esemény) nem találtak különbséget a két betegcsoport között (22).

\section{Megbeszélés, következtetések}

Az OM az első olyan új, egyedi hatásmechanizmusú gyógyszer, amely az aktin-miozin interakció direkt befolyásolása révén képes javítani a szívizom kontraktilitását (23). A GALACTIC-HF-vizsgálatban az OM kismértékben ugyan, de szignifikánsan csökkentette a CV-halálozás vagy a szívelégtelenség miatti események együttes előfordulását. $\mathrm{Az} \mathrm{OM}$ - a konvencionális pozitív inotróp szerekkel (pl. dobutamin, milrinon) ellentétben - nem növelte a CV-halálozást $(22,23)$. A fenti vizsgálatban az OM alkalmazása klinikai szempontból biztonságosnak bizonyult, a megfigyelt kismértékű troponin I-szint emelkedés jelentősége további vizsgálatokat igényel. A GALACTIC-HF-vizsgálat eredményei alapján az optimális gyógyszeres kezelés kiegészítéseként az OM-nek valószínüleg helye lesz a HFrEF kezelésében. Azt, hogy a gyógyszer alkalmazása fog-e, és ha igen, akkor milyen osztályú és evidenciaszintű ajánlással szerepelni az Európai Kardiológiai Társaság néhány hónapon belül megjelenő szívelégtelenség szakmai irányelvében nehéz megjósolni. Az OM HFrEF-betegek funkcionális kapacitására kifejtett hatását a jelenleg folyó METEORIC-HF-vizsgálat fogja tisztázni (26). A plazmakoncentráció rendszeres mérésének szükségessége (technikai és szervezési nehézségek, terápiás céltartomány elérése) és az esetleges, jelenleg még nem ismert mellékhatások korlátozhatják a szer klinikai alkalmazását (27).

\section{Köszönetnyilvánítás}

A publikáció az Innovációs és Technológiai Minisztérium ÚNKP-20-3 kódszámú új nemzeti kiválóság programjának a nemzeti kutatási, fejlesztési és innovációs alapból finanszírozott szakmai támogatásával készült. A kutatást a GINOP-2.3.2-15-2016-00048 számú, „Életet veszélyeztető akut megbetegedések súlyossági és halálozási mutatóinak javítása transzlációs orvostudományi megközelítésben - Stay Alive" címü projekt támogatta. A projekt az Európai Unió támogatásával, az Európai Regionális Fejlesztési Alap társfinanszirozásával valósult meg. A közlemény a TKP2020-NKA-04 számú projekt a Nemzeti Kutatási Fejlesztési és Innovációs Alapból biztosított támogatással, a 2020-4.1.1TKP2020 pályázati program finanszírozásában valósult meg. 


\section{Irodalom}

1. Tomcsányi J, Tóth E. Összefoglaló közlemény Szívelégtelenség epidemiológiája és terápiája Magyarországon a XXI. század elején. Cardiol Hungarica 2012; 42: 42.

2. Shah KS, Xu H, Matsouaka RA, Bhatt DL, Heidenreich PA, Hernandez AF, et al. Heart Failure With Preserved, Borderline, and Reduced Ejection Fraction: 5-Year Outcomes. J Am Coll Cardiol 2017 Nov; 70(20): 2476-86. https://doi.org/10.1016/j.jacc.2017.08.074 3. Chun S, Tu J V, Wijeysundera HC, Austin PC, Wang X, Levy D, et al. Lifetime analysis of hospitalizations and survival of patients newly admitted with heart failure. Circ Heart Fail 2012 Jul; 5(4): 414-21. https://doi.org/10.1161/CIRCHEARTFAILURE.111.964791

4. https://www.nuffieldtrust.org.uk/resource/cancer-survival-rates 5. Ambrosy AP, Fonarow GC, Butler J, Chioncel O, Greene SJ, Vaduganathan $\mathrm{M}$, et al. The global health and economic burden of hospitalizations for heart failure: lessons learned from hospitalized heart failure registries. J Am Coll Cardiol 2014 Apr; 63(12): 1123-33. 6. Ponikowski P, Voors AA, Anker SD, Bueno H, Cleland JGF, Coats AJS, et al. 2016 ESC Guidelines for the diagnosis and treatment of acute and chronic heart failure: The Task Force for the diagnosis and treatment of acute and chronic heart failure of the European Society of Cardiology (ESC) Developed with the special contribution o. Eur Heart J 2016 Jul; 37(27): 2129-200.

https://doi.org/10.1093/eurheartj/ehw128

7. Tacon CL, McCaffrey J, Delaney A. Dobutamine for patients with severe heart failure: a systematic review and meta-analysis of randomised controlled trials. Intensive Care Med 2012 Mar; 38(3): 35967. https://doi.org/10.1007/s00134-011-2435-6

8. Nieminen MS. Pharmacological options for acute heart failure syndromes: current treatments and unmet needs. Eur Hear J Suppl [Internet]. 2005 Apr 1; 7(suppl B): B20-4.

Available from: https://doi.org/10.1093/eurheartj/sui009

9. Endoh M. Cardiac $\mathrm{Ca}^{2+}$ signaling and $\mathrm{Ca}^{2+}$ sensitizers. Circ J 2008 Dec; 72(12): 1915-25. https://doi.org/10.1253/circj.cj-08-0838

10. Orstavik O, Ata SH, Riise J, Dahl CP, Andersen GØ, Levy FO, et al. Inhibition of phosphodiesterase- 3 by levosimendan is sufficient to account for its inotropic effect in failing human heart. $\mathrm{Br} \mathrm{J}$ Pharmacol 2014 Dec; 171(23): 5169-81. https://doi.org/10.1111/bph.12647

11. Teerlink JR. A novel approach to improve cardiac performance: cardiac myosin activators. Heart Fail Rev 2009 Dec; 14(4): 289-98. https://doi.org/10.1007/s10741-009-9135-0

12. Morgan BP, Muci A, Lu P-P, Qian X, Tochimoto T, Smith WW, et al. Discovery of omecamtiv mecarbil the first, selective, small molecule activator of cardiac Myosin. ACS Med Chem Lett 2010 Dec; 1(9): 472-7. https://doi.org/10.1021/ml100138q

13. Katz AM, Lorell BH. Regulation of cardiac contraction and relaxation. Circulation 2000 Nov; 102(20 Suppl 4): IV69-74.

https://doi.org/10.1161/01.cir.102.suppl_4.iv-69

14. Planelles-Herrero VJ, Hartman JJ, Robert-Paganin J, Malik FI, Houdusse A. Mechanistic and structural basis for activation of cardiac myosin force production by omecamtiv mecarbil. Nat Commun 2017 Aug; 8(1): 190. https://doi.org/10.1038/s41467-017-00176-5 15. Nagy L, Gödény I, Nánási $P$, Leskó Á, Balogh L, Bánhegyi V, et al. A szív pozitív inotróp támogatása a miozin-aktivátor hatású omecamtiv mecarbil segítségével. Cardiol Hungarica 2017; 47(2): $145-52$.

16. Teerlink JR, Clarke CP, Saikali KG, Lee JH, Chen MM, Escandon $\mathrm{RD}$, et al. Dose-dependent augmentation of cardiac systolic function with the selective cardiac myosin activator, omecamtiv mecarbil: a first-in-man study. Lancet (London, England) 2011 Aug; 378(9792): 667-75. https://doi.org/10.1016/S0140-6736(11)61219-1

17. Cleland JGF, Teerlink JR, Senior R, Nifontov EM, Mc Murray JJ V, Lang CC, et al. The effects of the cardiac myosin activator, omecamtiv mecarbil, on cardiac function in systolic heart failure: a double-blind, placebo-controlled, crossover, dose-ranging phase 2 trial. Lancet (London, England) 2011 Aug; 378(9792): 676-83.

https://doi.org/10.1016/S0140-6736(11)61126-4

18. Greenberg BH, Chou W, Saikali KG, Escandón R, Lee JH, Chen MM, et al. Safety and tolerability of omecamtiv mecarbil during exercise in patients with ischemic cardiomyopathy and angina. JACC Heart Fail 2015 Jan; 3(1): 22-9.

https://doi.org/10.1016/j.jchf.2014.07.009

19. Teerlink JR, Felker GM, McMurray JJV, Ponikowski P, Metra M, Filippatos GS, et al. Acute Treatment with Omecamtiv Mecarbil to Increase Contractility in Acute Heart Failure: The ATOMIC-AHF Study. J Am Coll Cardiol 2016; 67(12): 1444-55.

https://doi.org/10.1016/j.jacc.2016.01.031

20. Teerlink JR, Felker GM, McMurray JJ V, Solomon SD, Adams KFJ, Cleland JGF, et al. Chronic Oral Study of Myosin Activation to Increase Contractility in Heart Failure (COSMIC-HF): a phase 2, pharmacokinetic, randomised, placebo-controlled trial. Lancet (London, England) 2016 Dec; 388(10062): 2895-903.

https://doi.org/10.1016/S0140-6736(16)32049-9

21. Teerlink JR, Diaz R, Felker GM, McMurray JJ V, Metra M, Solomon SD, et al. Omecamtiv Mecarbil in Chronic Heart Failure With Reduced Ejection Fraction: Rationale and Design of GALACTIC-HF. JACC Heart Fail 2020 Apr; 8(4): 329-40.

https://doi.org/10.1016/j.jchf.2019.12.001

22. Teerlink JR, Diaz R, Felker GM, McMurray JJ V, Metra M, Solomon SD, et al. Cardiac Myosin Activation with Omecamtiv Mecarbil in Systolic Heart Failure. N Engl J Med 2021 Jan; 384(2): 105-16. https://doi.org/10.1056/NEJMoa2025797

23. Teerlink JR, Metra M, Zacà V, Sabbah HN, Cotter G, Gheorghiade $M$, et al. Agents with inotropic properties for the management of acute heart failure syndromes. Traditional agents and beyond. Heart Fail Rev 2009 Dec; 14(4): 243-53.

https://doi.org/10.1007/s10741-009-9153-y

24. O'Connor CM, Gattis WA, Uretsky BF, Adams KFJ, McNulty SE, Grossman SH, et al. Continuous intravenous dobutamine is associated with an increased risk of death in patients with advanced heart failure: insights from the Flolan International Randomized Survival Trial (FIRST). Am Heart J 1999 Jul; 138(1 Pt 1): 78-86.

https://doi.org/10.1016/s0002-8703(99)70250-4

25. Packer M, Carver JR, Rodeheffer RJ, Ivanhoe RJ, DiBianco R, Zeldis SM, et al. Effect of oral milrinone on mortality in severe chronic heart failure. The PROMISE Study Research Group. N Engl J Med 1991 Nov; 325(21): 1468-75.

https://doi.org/10.1056/NEJM199111213252103

26. https://clinicaltrials.gov/ct2/show/NCT03759392

27. Fülöp GÁ, Oláh A, Csipo T, Kovács Á, Pórszász R, Veress R, Horváth $B$, Nagy L, Bódi B, Fagyas M, Helgadottir SH, Bánhegyi V, Juhász B, Bombicz M, Priksz D, Nanasi PJr, Merkely B, Édes I, Csanádi Z, Papp Z, Radovits T, Toth A. Omecamtiv mecarbil evokes diastolic dysfunction and leads to periodic electromechanical alternans. Basic Res Cardiol 2021 Apr 12; 116(1): 24.

https://doi.org/10.1007/s00395-021-00866-8 